Article (refereed) - postprint

Kentisbeer, J.; Leeson, S.R.; Clark, T.; Malcolm, H.M.; Cape, J.N. 2015.

Influences on and patterns in total gaseous mercury (TGM) at Harwell, England. Environmental Science: Processes and Impacts, 17 (3). 586-595. $\underline{10.1039 / C 4 E M 00652 F}$

Copyright (C) The Royal Society of Chemistry 2015

This version available http://nora.nerc.ac.uk/509493/

NERC has developed NORA to enable users to access research outputs wholly or partially funded by NERC. Copyright and other rights for material on this site are retained by the rights owners. Users should read the terms and conditions of use of this material at

http://nora.nerc.ac.uk/policies.html\#access

This document is the author's final manuscript version of the journal article following the peer review process. There may be some differences between this and the publisher's version. You are advised to consult the publisher's version if you wish to cite from this article.

http://www.rsc.org

Contact CEH NORA team at noraceh@ceh.ac.uk

The NERC and CEH trademarks and logos ('the Trademarks') are registered trademarks of NERC in the UK and other countries, and may not be used without the prior written consent of the Trademark owner. 


\section{Influences on and patterns in total gaseous mercury (TGM) at Harwell, England}

Authors: J Kentisbeer, S.R. Leeson, T Clark, H.M. Malcolm and J.N. Cape

\section{Abstract}

Total Gaseous Mercury (TGM) was monitored during 2013 at the rural monitoring site, Harwell, England using the Tekran 2537A monitoring system. Average TGM for the year was $1.45 \pm 0.24 \mathrm{ng} \mathrm{m}^{-3}$. This is comparable to other northern hemisphere studies, but on average $0.05 \mathrm{ng} \mathrm{m}^{-3}$ higher than at its sister monitoring station at Auchencorth Moss, Scotland, but 14\% lower than that found in a similar study at the same location of $1.68 \mathrm{ng} \mathrm{m}^{-3}$ in 1995/6. Using wind sector analysis we show the important influence of local emissions, with our data showing that the largest influence on TGM observed is that of the adjacent Science \& Innovation campus, making the site more a 'suburban background'. By using co-located measurements of black carbon and sulphur dioxide as tracers, we present an initial investigation into the impact of the closure of Didcot A coal fired power station, which ceased operating in March 2013. Further analysis using air mass back trajectories shows the long-range contribution to TGM from continental Europe, and that the lowest levels are associated with marine air masses from the west.

Key Words: TGM, atmospheric mercury, monitoring

\section{Introduction}

The atmosphere receives mercury from three sources: anthropogenic emissions, natural emissions and re-emissions. Precise figures for these emission types are not certain, but it is thought that natural emissions (including releases from volcanoes, geothermal systems, oceanic emissions ${ }^{1}$ as well as erosion, amongst others) comprise about $10 \%$ of emissions to the atmosphere ${ }^{2-}$ 6. Anthropogenic emissions (those directly originating from man-made operations, such as consumer waste, chemical manufacture, cement production, oil refining, coal burning, mining (both large scale and artisanal) and smelting) are thought to comprise about $30 \%$ of emissions ${ }^{4,7-10}$. The remaining $60 \%$ of emissions of mercury to the atmosphere are thought to be from previously deposited mercury being re-emitted, such as mercury deposited in surface waters, vegetation or surface soils, which is subsequently returned to 
the atmosphere through processes such as forest fires, biomass burning or evaporation from surface deposits ${ }^{4,11}$.

There are three major forms of atmospheric mercury: gaseous elemental mercury (GEM), gaseous oxidised mercury (GOM) and particulate bound mercury (PBM). GEM is the predominant form, making up $>95 \%$ of total atmospheric mercury ${ }^{12,13}$. In this form mercury is mostly unreactive, with low wet and dry deposition rates ${ }^{14}$, making this the leading vector by which mercury is transported in the global mercury cycle.

GOM has a +2 oxidation state within inorganic compounds ${ }^{15}$, and is partly formed through oxidation processes in the atmosphere reacting GEM with $\mathrm{O}_{3} / \mathrm{OH} / \mathrm{Br} / \mathrm{BrO}$ to form species like $\mathrm{HgO}, \mathrm{HgBr}_{2}, \mathrm{Hg}(\mathrm{OH})_{2}{ }^{12,}{ }^{13}, 16$, in which the reaction with bromine is likely to be predominant ${ }^{17}$. However, the main source for GOM in the atmosphere is through direct emission from point sources, where the exact composition of species is more varied depending on the emission source. The lifetime of such species in the atmosphere is relatively short as they are easily removed through both dry and wet deposition processe ${ }^{14,18-20}$ and is probably limited to between a few hours to a few weeks ${ }^{12}$, ${ }^{21}$. The exact lifetime will depend on meteorological conditions as well as atmospheric pollutant/plume composition ${ }^{22}$, with a deposition footprint in the order of $10^{2}$ to $10^{3} \mathrm{~km}$ from the emission source. In polar regions GOM is particularly important in the cycling of mercury. At polar sunrise, large atmospheric mercury depletion events (AMDEs) have been seen to occur, caused by rapid photochemical oxidation of GEM by halogen radicals to form GOM and ozone ${ }^{23-25}$. AMDEs have also been observed in the Dead Sea region, attributed to bromine oxidation ${ }^{26}$ whilst AMDEs in South Africa have been observed which are not related to bromine chemistry ${ }^{27}$.

PBM can arise from three processes: direct emission from point sources, adsorption of GEM and GOM on to pre-existing particles, and formation in the atmosphere from $\mathrm{GOM}^{28}$. It has an atmospheric lifetime similar to that of GOM, with removal from the atmosphere though both wet and dry deposition processes $^{14,29,30 .}$

Concentrations of mercury in the atmosphere increased dramatically from the 1800s due to the industrial revolution and numerous global gold rushes ${ }^{31,32}$, coming to a peak in the early 1980 s, as can be seen in both lake sediment and 
glacier ice core records ${ }^{33-35}$. Through improvements in industrial processes and emission controls, atmospheric mercury levels have been gradually declining since then ${ }^{36,37}$, and currently the average northern hemispherical background concentration is between 1.4 and $1.7 \mathrm{ng} \mathrm{m}^{-3} .22,36,38-40$

Ever since the diagnosis of Minamata disease in $1960^{41}$, the effects of mercury on the health of both humans ${ }^{42}$ and wildlife ${ }^{43,44}$ has made the interest in atmospheric mercury more prominent, with the highest risk to human health thought to be through the consumption of fish with elevated levels of mercury, which have bioaccumulated through the food chain into higher predators ${ }^{45-47}$. Health policy reflects this risk, with several industrialised countries issuing fish consumption guidelines. The inclusion of mercury in the United Nations Economic Commission for Europe (UNECE) convention on Long-Range Transboundary Air Pollution (LRTAP) ${ }^{15}$, with the European Air Framework $4^{\text {th }}$ Daughter Directive, requires monitoring of mercury through the European Monitoring and Evaluation programme (EMEP). In 2013, the UNEP Minamata Convention was opened for signature, designed to protect human health and the environment from the release of mercury and its compounds from anthropogenic sources ${ }^{48}$.

The different forms of mercury in the atmosphere have been measured at numerous locations and in various scenarios globally in order to better understand its transport and fate, however there have been few studies in the UK. One study by Lee et al. in $1998^{15}$, sampled Total Gaseous mercury (TGM, which is a measure of both GEM and GOM combined) at Harwell, England between June 1995 and April 1996. The work presented in this paper provides an update and a comparison with other studies that have been conducted in the intervening 18 years.

\section{Materials and Methods}

\subsection{Site description}

Total gaseous mercury measurements were made between November 2012 and December 2013 at the Harwell field site operated by Ricardo-AEA on behalf of the UK Government Department for the Environment, Food and Rural Affairs (Defra). The site is in Oxfordshire, England, $\sim 26 \mathrm{~km}$ south of the city of Oxford at $51^{\circ} 34^{\prime} 15^{\prime \prime} \mathrm{N}, 1^{\circ} 19^{\prime} 30^{\prime \prime} \mathrm{W}$ (Figure S1). The site is classified as 'rural background', surrounded predominantly by arable farmland, but situated close to the Harwell 
Science and Innovation Campus (Figure 1). Monitoring of atmospheric pollutants began at the site as far back as $1976^{49}$; during the 2000s it was made a Level II supersite, forming part of the Co-operative Programme for Monitoring and Evaluation of Long-range Transmission of Air Pollutants in Europe (EMEP). As such it measures a wider range of pollutants than EMEP Level I sites ${ }^{50}$ (http://emep.int).

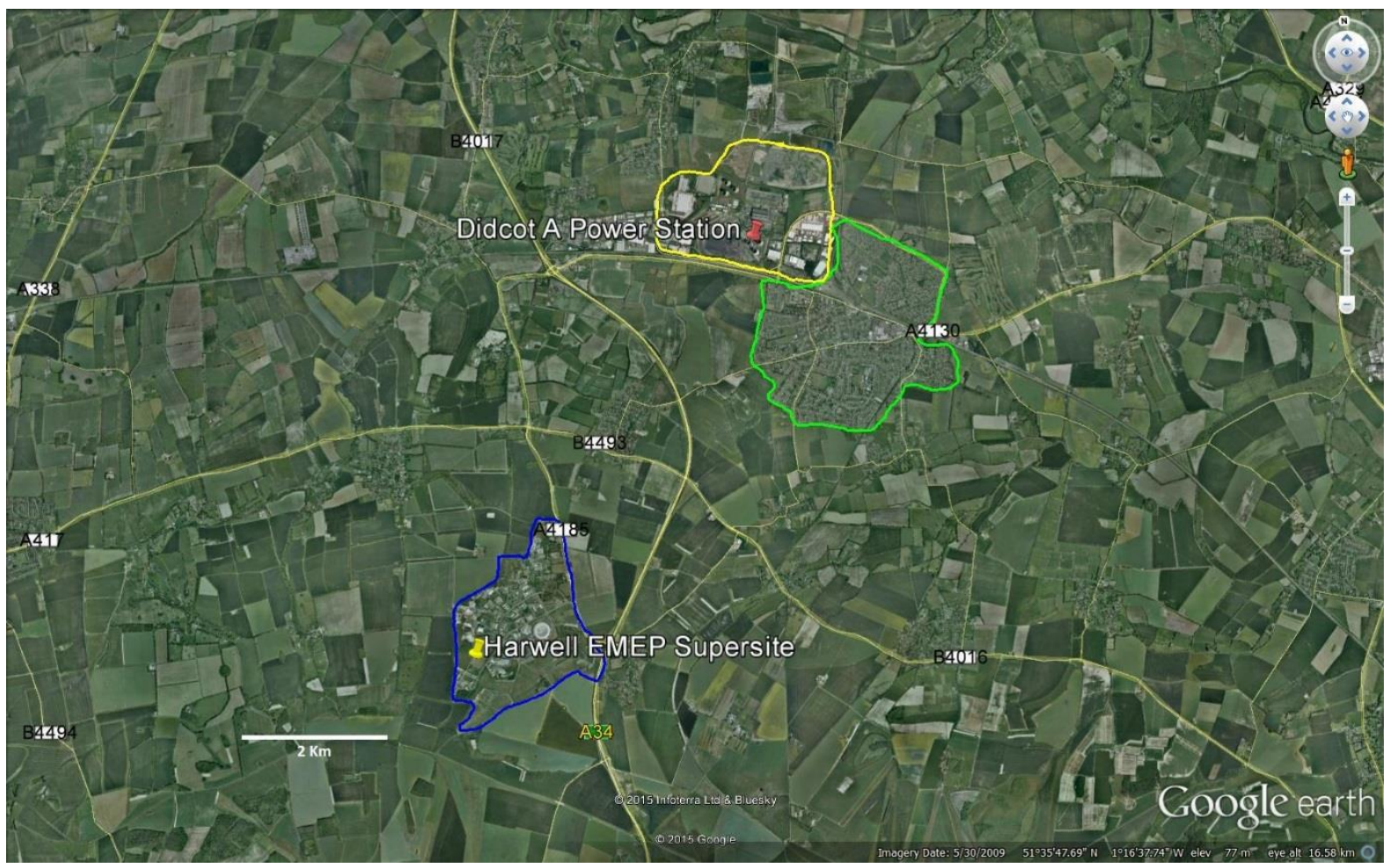

Figure 1: The Location of the Harwell EMEP Supersite, showing the adjacent Science and Innovation Campus (blue) to its immediate north-east, and Didcot Town (green) and Didcot Power Stations (yellow).

\subsection{Mercury Analyser}

Measurements of TGM were made using a Tekran 2537A mercury analyser. The inlet samples air at $1 \mathrm{~L} \mathrm{~min}^{-1}$ at a height of $\sim 4 \mathrm{~m}$, the air flow is filtered just prior to entering the analyser (which removed PBM) and the $0.2 \mu \mathrm{m}$ PTFE filter paper is changed monthly. The analyser uses an automated dual channel amalgamation technique and Cold Vapour Atomic Fluorescence Spectroscopy (CVAFS, $253.7 \mathrm{~nm}$ ) to detect $\mathrm{GEM}^{51}$. The dual channel system allows sampling of ambient air at a 5 minute time resolution, by pre-concentrating mercury on to one of two gold cartridges, whilst at the same time the other cartridge is desorbed and analysed. 
The instrument was automatically calibrated every 25 hours by an internal permeation source. These were two-point calibrations consisting of a zero and a span on each cartridge, with the permeation source releasing $\sim 1 \mathrm{pg} \mathrm{s}^{-1} @ 50$ ${ }^{\circ} \mathrm{C} .126 \mathrm{pg}$ of mercury are released from the permeation source during each auto calibration, which gives an effective concentration of $25.15 \mathrm{ng} \mathrm{m}^{-3}$, a level well above ambient. The efficiency of the permeation source was validated annually using source verification tests using an external calibration source (Tekran 2505). With this we inject saturated mercury vapour of known quantities, so as to bracket the permeation rate of the internal source, which in turn verifies the emission rate and therefore calibration accuracy ${ }^{51}$. The stated manufacturer limit of detection is $<0.1 \mathrm{ng} \mathrm{m}^{-3} .{ }^{52}$

The data presented in this paper are hourly average values of the five minute resolution data, e.g. the 12 values between 12:00 and 13:00. For the purposes of air-mass back trajectories and associating other meteorological or pollutant data to the dataset, then end time of the measurement averages is used, i.e. for 12:00-13:00, the back trajectory and other associated data would be based on 13:00. All times are recorded as GMT.

\subsection{Data analysis methods}

Air mass back trajectories for Harwell were calculated at three hour intervals using the NOAA HYSPLIT trajectory Model (Hybrid Single Particle Lagrangian Integrated Trajectory Model) ${ }^{53}$ with the Global NOAA/NCAR reanalysis data archive. These 96 hours back trajectories were run with a start height of $10 \mathrm{~m}$ above ground level to best represent the inlet height for the analyser. The back trajectories were imported into the OpenAir ${ }^{54}$ package in $\mathrm{R}$ statistical software ${ }^{55}$ for analysis of the mercury data. OpenAir is an open source package add-on for the $\mathrm{R}$ software, which has been specifically designed for the analysis of air pollution data. The development of the package was co-funded by the UK Natural Environment Research Council (NERC), Kings College London, UK Department for the Environment Food and Rural Affairs (Defra) and the University of Leeds.

\section{Results and Discussion}

\subsection{Measurement overview}


Figure S2 shows the time series for the hourly average TGM observations at the Harwell site, also showing the frequency distribution of the data and summary statistics. The 2013 annual mean and standard deviation were 1.45 and $0.24 \mathrm{ng}$ $\mathrm{m}^{-3}$ respectively. This is in very good agreement with recent measurement of GEM, PBM and GOM at a rural monitoring site in Southern Scotland, which showed a three year average GEM value of $1.40 \pm 0.19 \mathrm{ng} \mathrm{m}^{-3} \cdot{ }^{56} \mathrm{It}$ also agrees well with interpolated TGM concentrations over the UK from a rural atmospheric mercury monitoring network, which predicted a concentration at Harwell between 1.42 and $1.49 \mathrm{ng} \mathrm{m}^{-3}$ between 2005 and $2008^{57}$. The value observed at Harwell in 2013 is also consistent with other studies in the northern hemisphere (Table 1), indicating that the site is representative of the northern hemispherical background. The earlier study at Harwell ${ }^{29}$ showed an average of $1.68 \mathrm{ng} \mathrm{m}^{-3}$, so this latest work indicates a 14\% decline in TGM levels at the site over the intervening 18 years. Other studies have reported a $25 \%$ decline in TGM between $1996-2010^{58}$ and 20-38\% decline globally between 1996 and 2010 from various monitoring sites and activities ${ }^{36}$.

Table 1: GEM and TGM concentrations from other atmospheric mercury monitoring studies at locations in the northern hemisphere. *Average and standard deviation based on mean monthly averages presented in Ebinghaus et al, $2011^{58}$.

\begin{tabular}{|c|c|c|c|c|c|}
\hline Place & Dates & GEM & sd & TGM & sd \\
\hline Yorkville, GA, USA ${ }^{59}$ & $2007-8$ & 1.35 & 0.17 & & \\
\hline CAMNet $^{23}$ & 1995-05 & & & 1.58 & 0.17 \\
\hline Salmon Falls Creek Reservoir, ID, USA ${ }^{39}$ & $2005-06$ & 1.57 & 0.6 & & \\
\hline Huntingdon Forest, NY, USA ${ }^{60}$ & 2007-09 & 1.3 & 0.4 & & \\
\hline Dexter, MI, USA ${ }^{61}$ & 2004 & 1.59 & 0.59 & & \\
\hline Harwell, UK ${ }^{29}$ & $1995-96$ & & & 1.68 & \\
\hline Lista, Norway ${ }^{62}$ & 1995-02 & & & 1.79 & \\
\hline Mace Head, Ireland ${ }^{63}$ & 1995-02 & & & 1.75 & \\
\hline Mace Head, Ireland ${ }^{58}$ & $1996-09 *$ & & & 1.65 & 0.13 \\
\hline Zinghst, Germany ${ }^{64}$ & 1998-04 & & & 1.66 & \\
\hline St Ancient, Quebec, Canada ${ }^{40}$ & 2005 & 1.65 & 0.42 & & \\
\hline Waldhof, Germany ${ }^{65}$ & 2009-11 & 1.61 & & & \\
\hline AMNet (Rural Sites only) ${ }^{66}$ & $2009-11$ & $1.2-1.5$ & & & \\
\hline Auchencorth Moss, Scotland ${ }^{56}$ & 2009-11 & 1.40 & 0.19 & & \\
\hline
\end{tabular}

Both Harwell and Auchencorth Moss have lower annual averages than other monitoring sites, but other more land-locked sites in Europe and Asia are more 
likely to be influenced by continental air-masses which are more polluted in nature, meaning they may not be directly comparable to the sites in the UK, which generally experience cleaner, westerly flows from the Atlantic Ocean.

\subsection{Temporal Patterns}

Figure 2 shows time variation plots for TGM; the solid line represents the average of the data with the shaded area comprising the $95 \%$ confidence interval in the mean.
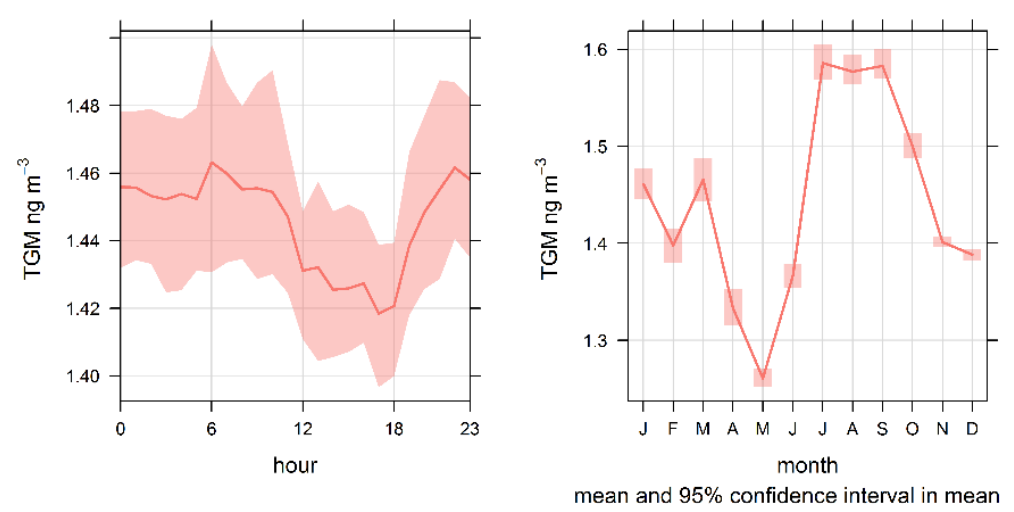

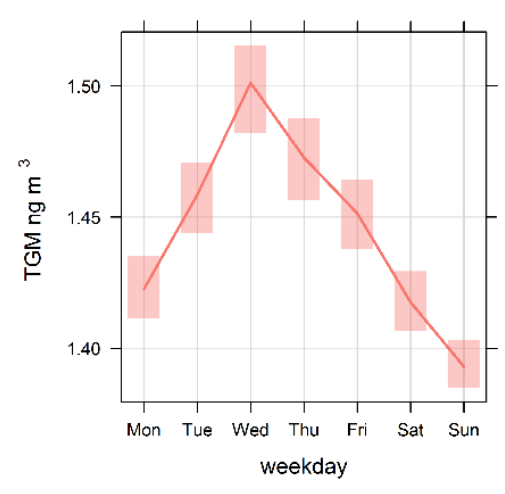

Figure 2: Time variation plot for TGM ( $\mathrm{ng} \mathrm{m}^{-3}$ ) showing variation by hour, month and day of the week. Plots generated using OpenAir ${ }^{53}$

The first plot indicates the diurnal cycle for the 2013 dataset which shows a maximum during the night and a minimum during the day. This is in marked contrast to the Auchencorth site ${ }^{55}$, which had a clear night time minimum and daytime maximum. However, this pattern is consistent with the 1995-6 study at Harwell ${ }^{15}$, which showed a $0.2 \mathrm{ng} \mathrm{m}^{-3}$ decrease between the night time maximum and daytime minimum, but with a smaller diurnal range of $0.04 \mathrm{ng} \mathrm{m}^{-}$ ${ }^{3}$. The pattern is most pronounced during winter (Nov-Jan) and summer (MayJul) quarters (data not shown), with the winter showing a difference of $0.06 \mathrm{ng}$ $\mathrm{m}^{-3}$ and summer $0.13 \mathrm{ng} \mathrm{m}^{-3}$, representing decreases of $4 \%$ and $9 \%$ respectively. A similar pattern can be seen in data from co-located instruments measuring black carbon, ethane and particulate matter, which all have night time maxima (data not shown - available from http://uk-air.defra.gov.uk/).

The patterns observed at both Auchencorth Moss and Harwell are probably caused by the effects of the nocturnal boundary layer. At Auchencorth, sources of mercury are remote from the site, and as such, little mercury is trapped or released into the boundary layer at night close to the site, but during the day, with solar radiation and temperature increases, mercury is re-emitted from 
surfaces on which it has deposited, combined with greater vertical mixing and transport, increasing the concentration to the daily maximum. At Harwell the inverse is true. Harwell's semi-rural position closer to point source emissions means that as mercury is released into the nocturnal boundary layer, with little mixing, the TGM concentrations increase to a night time maximum. During the day, with increased mixing, the concentration decreases to the daytime minimum. This pattern is contrary to most other studies at rural locations ${ }^{39,56 \text {, }}$ $57,59,65,67,68$, but has been observed in some studies, including Harwell in $1995 / 6^{29}$, and also in Chicago ${ }^{69}$, Seoul ${ }^{70}$ and Birmingham $A^{59}$. This pattern is generally observed at urban locations, ${ }^{67,71,72}$ where sources for emission and reemission are more important under any nocturnal boundary layer.

The pattern of weekly averages is consistent between seasons, with a peak in observed concentrations mid-week falling away towards the weekend minimum, with an absolute range of $0.1 \mathrm{ng} \mathrm{m}^{-3}$. This is most likely the effect of increased activity in the locale, but was an effect also noted at the Auchencorth Moss site ${ }^{55}$, albeit not statistically significant.

The seasonal pattern within the data indicates a maximum in the summer and a minimum during spring, which is not consistent with other rural studies ${ }^{58,65,72}$. At Auchencorth Moss, for example, the peak levels were observed during the winter/spring and the lowest during the autumn. This could be due to local activity on the Science Campus being greater over the summer, or the effect of meteorological factors such as warmer temperatures during the summer months or increased levels of solar radiation, both of which could lead to more emission or reemission. It is not known whether this is typical for this site; a larger multi-year dataset would be required.

On the $22^{\text {nd }}$ March 2013, Didcot A power station (coal / gas-fired) was closed down. This allows us the opportunity to assess the impact of the power station on the TGM measurements at the Harwell site by comparing the pre- and postshutdown datasets. The average ( \pm standard deviation) for pre-Didcot A closing was $1.47 \pm 0.28 \mathrm{ng} \mathrm{m}^{-3}(\mathrm{n}=1675)$ and post-Didcot A closing was $1.44 \pm 0.23 \mathrm{ng}$ $\mathrm{m}^{-3}(\mathrm{n}=6525)$. The difference in means is statistically significant according to a non-paired t-test at $\mathrm{p}<0.01$, with a test statistic $\mathrm{T}=4.19, \mathrm{p}=2.8 \times 10^{-5}$, and represents a $2 \%$ decrease in average TGM. Figure $S 4$ shows the comparative temporal plots for pre- and post- closure, showing that diurnally there was far 
greater spread in the data over higher concentrations before closure and no afternoon dip. Concentrations under any nocturnal boundary layer were also generally higher after closure. The weekday plot shows higher average daily concentrations before closure during the middle of the week. However, the extent to which the differences in these observations are typical, or the sole effect of shutting down the power station is currently unknown, as we cannot exclude other factors such as a greater frequency of particular meteorological conditions which could give rise to high concentrations during that period. A larger dataset for pre- and post- closure would be required to properly take into account any seasonal variation in measured TGM.

\subsection{Spatial Patterns}

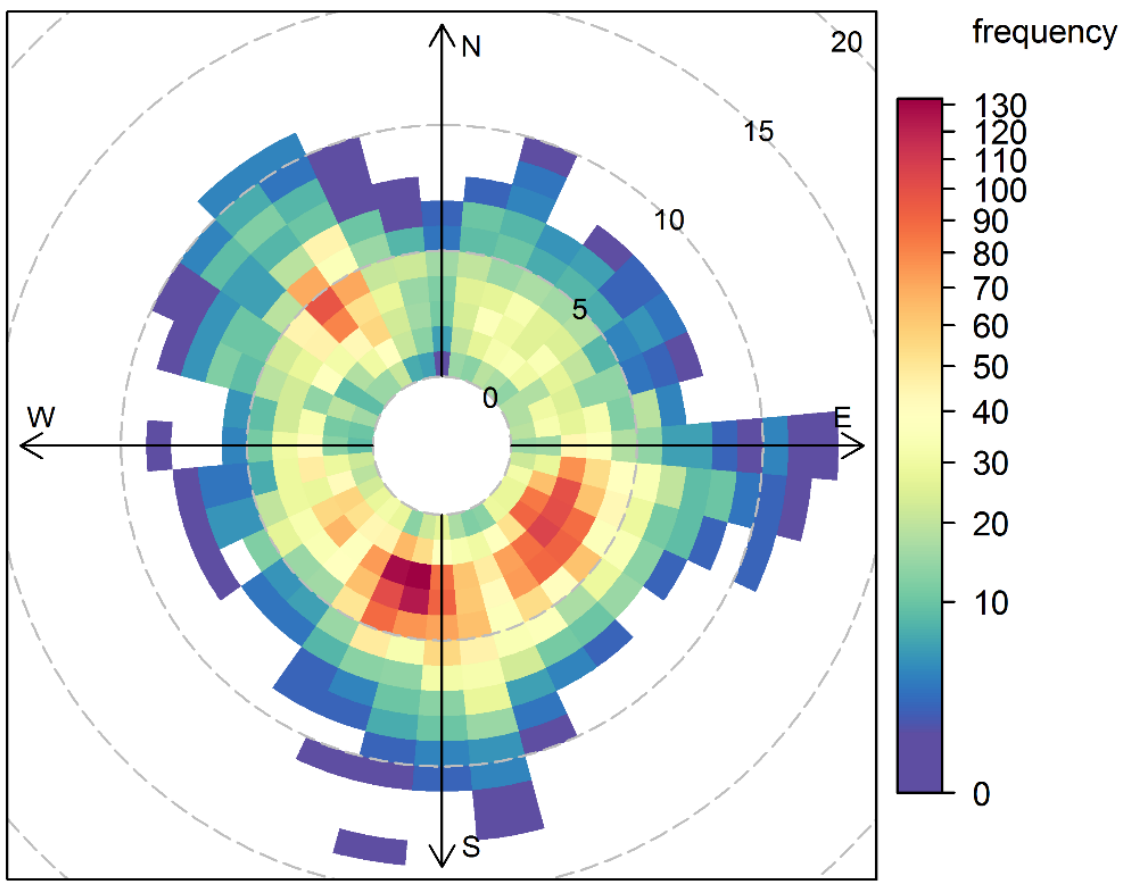

Figure 3: Polar Frequency plot of wind speed $\left(\mathrm{m} \mathrm{s}^{-1}\right)$ and direction at Harwell. Plot generated using OpenAir ${ }^{53}$ 


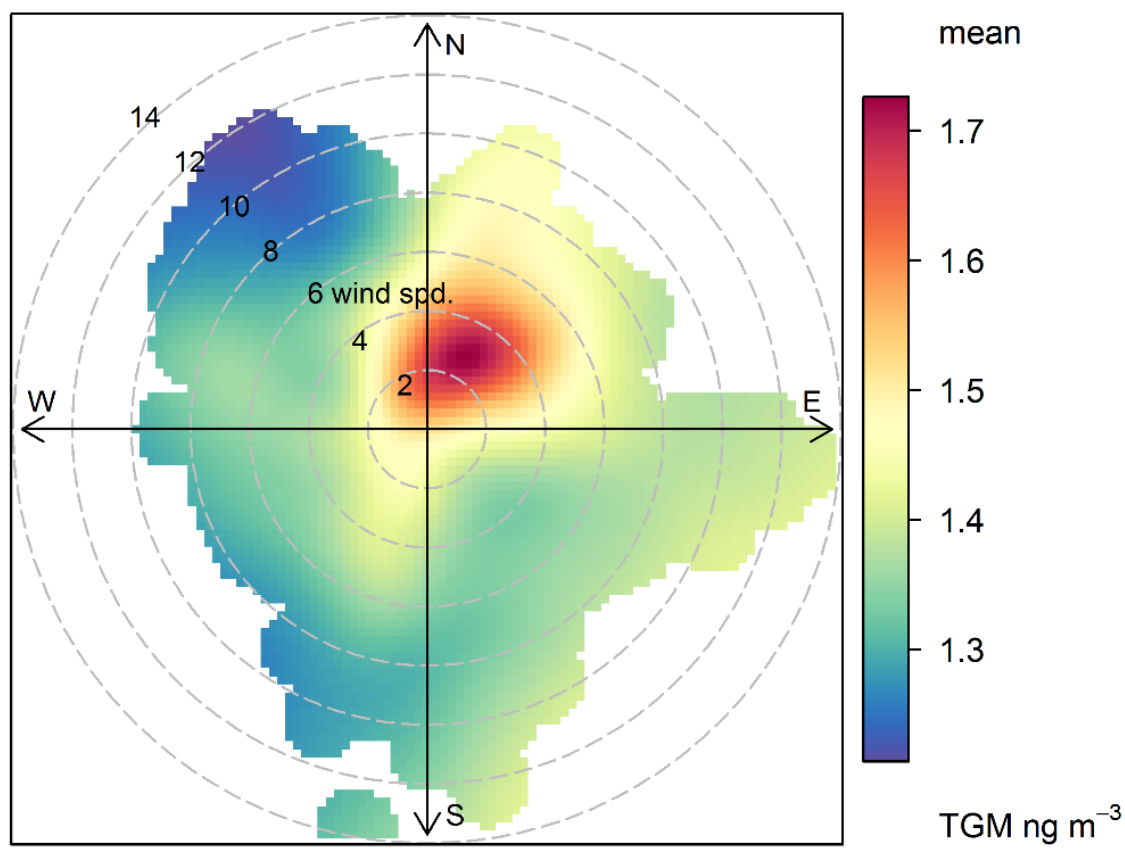

Figure 4: Polar plot for arithmetic mean TGM, showing the variation in concentration by wind speed $\left(\mathrm{m} \mathrm{s}^{-1}\right)$ and direction. Plot generated using OpenAir ${ }^{53}$

In order to understand potential sources and influence on TGM concentration observed at Harwell, we have looked at the UK Pollutant Release \& Transfer Register for mercury releases during $2012^{73}$ (2013 data were not available at the time of writing). Figure $\mathrm{S} 3$ shows that the largest local emitter was Didcot A coalfired power station, situated $6 \mathrm{~km}$ NNE of the Harwell site. The largest UK emitters are in Northern England, around Manchester and Leeds.

Figure 3 shows a polar frequency plot of wind direction for Harwell. This shows that wind direction at Harwell has higher frequencies from the south-southwest, south-east and north-west. Figure 4 shows how concentrations of TGM vary at Harwell with respect to wind speed and direction. Average TGM concentrations are elevated when the surface winds come from the north-east, with the highest average concentrations at wind speeds between 2 and $5 \mathrm{~m} \mathrm{~s}^{-1}$. There is also evidence of some higher concentrations from the south-southwest, as evident from the yellow 'finger' and also overall higher concentrations to the south-east at higher wind speeds (yellow 'glow'). These correlate well with the higher frequency wind directions.

The higher concentrations to the north-east are likely due to the impact of the Harwell Science and Innovation Campus and the Didcot A power station site about $6 \mathrm{~km}$ distant. There is a crematorium located on the outskirts of the city 
of Oxford, which could also be a potential source to the north-east, however the emissions are fully abated at this facility ${ }^{74}$. The higher concentrations to the south-south-west are probably activity on the campus south of the monitoring site, whilst the higher concentrations to the south east, the 'yellow glow' are likely evidence of long-range transport of continental air-masses impacting the site.

Lee et al attempted to assess the impact of the power station in their 1997 paper ${ }^{15}$ by correlation of TGM and $\mathrm{SO}_{2}$ as a trace indicator for the power station. They partitioned the data at various $\mathrm{SO}_{2}$ concentrations to try to isolate the point source contribution, but as they looked at increasingly higher concentrations, the correlation coefficient decreased. They were therefore unable to show a direct impact of the source on their dataset.

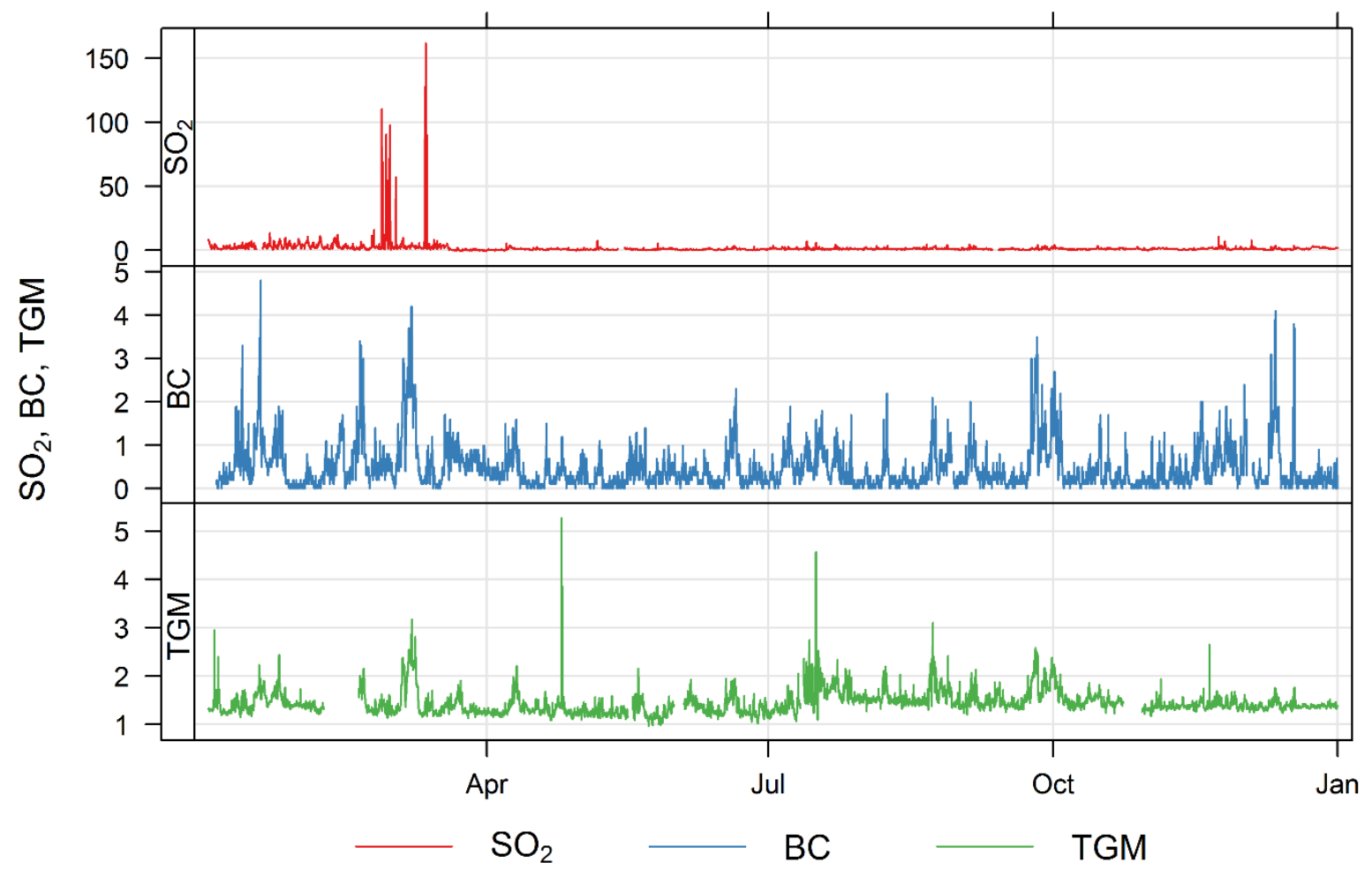

Figure 5: Time plots of $\mathrm{SO}_{2}(\mathrm{ppb})$, Black Carbon $\left(\mu \mathrm{g} \mathrm{m}^{-3}\right)$ and TGM $\left(\mathrm{ng} \mathrm{m}^{-3}\right)$ for 2013. (Generated using OpenAir.)

The same is still true for the 2013 dataset presented here. Figure 5 shows the time series for $\mathrm{SO}_{2}$ at Harwell during 2013, in which one can clearly see when Didcot A closed. During operation, $\mathrm{SO}_{2}$ levels were noticeably higher and more variable; after closure they became slightly lower and more stable. Lee et al ${ }^{15}$ found a correlation coefficient of $r=0.34, P<0.0009, n=3622$. We find no 
significant correlation $(r=-0.02, P=0.423, n=1610)$ during operation and a significant correlation of $(r=0.34, P<0.00001 n=6421)$ after shut down, implying little direct influence of the power station on TGM measured at the site.
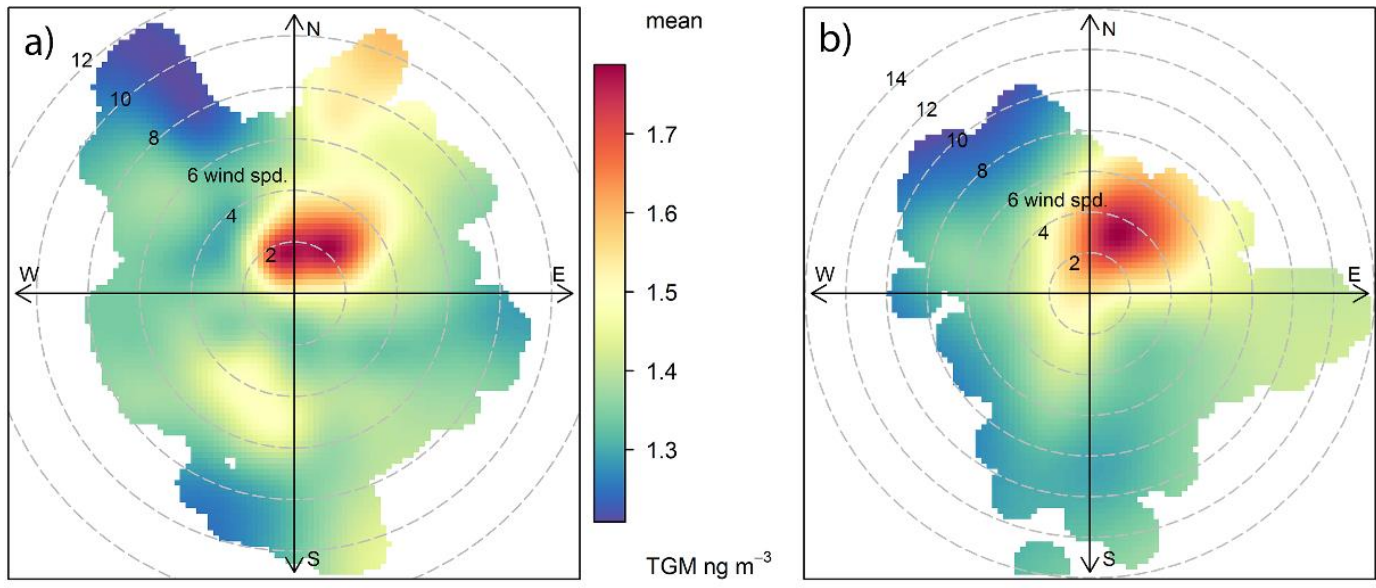

mean
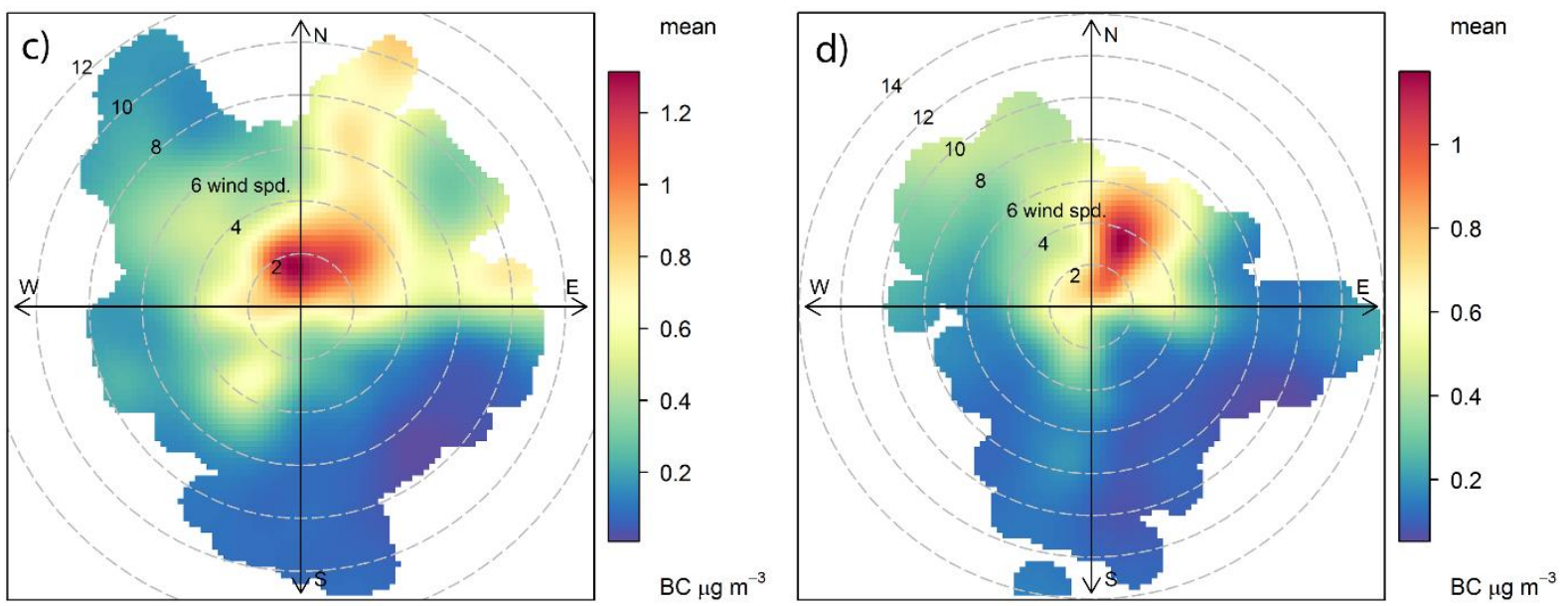

Figure 6: Polar Plots showing direction dependence and variation with wind speed ( $\mathrm{m} \mathrm{s}^{-1}$ ) of (top row), TGM before Didcot $A$ shut down, TGM after Didcot A shut down, (bottom row) BC before Didcot $A$ shut down and BC after Didcot $A$ shut down. (Generated using OpenAir.)

We have found that measurements of Black Carbon (BC) can be used as an alternative tracer for point source emissions from Didcot $A$. Figure 5 shows time plots for BC and TGM data. The correlation coefficient for BC and TGM during 2013 was $r=0.62, P<0.00001, n=8081$, which is good evidence for common sources for the two species. (Correlation before shut down is $r=0.81, p<$ $0.00001, n=1615$, and after shut down is $r=0.54, p<0.00001, n=6466$.) Figure 6 shows polar plots for TGM and BC before and after Didcot $A$ closed. Other trace gas and aerosol measurements are available (NO, NO $\mathrm{NO}_{2}, \mathrm{PM}_{2.5}, \mathrm{PM}_{10}$ ) but substantial portions of the 'post shut down' dataset are missing (between 40$60 \%$ of the annual dataset). Figure $6 a$ shows the impact of the local science campus to the north and north-east on wind speeds $<4 \mathrm{~m} \mathrm{~s}^{-1}$. The impact from 
Didcot $A$ is clearly seen further to the north, particularly with wind speeds $>6 \mathrm{~m}$ $\mathrm{s}^{-1}$. In figure $6 \mathrm{~b}$, after Didcot A ceased operating, the polar plots for TGM and BC show only the impact of the science campus, although higher wind speeds from the direction of Didcot are absent during the latter part of this study. These plots imply that the origin of TGM measured at Harwell changed before and after the closure of the power station, but the limited dataset cannot prove a direct causal influence.

\subsection{Air mass back trajectories and cluster analysis}

Using air mass back trajectories allows us to look at where air masses have originated from and what they have passed over before arriving at the Harwell site. Assigning the TGM value observed at the site to the air mass origin allows the creation of maps to identify patterns in the data.

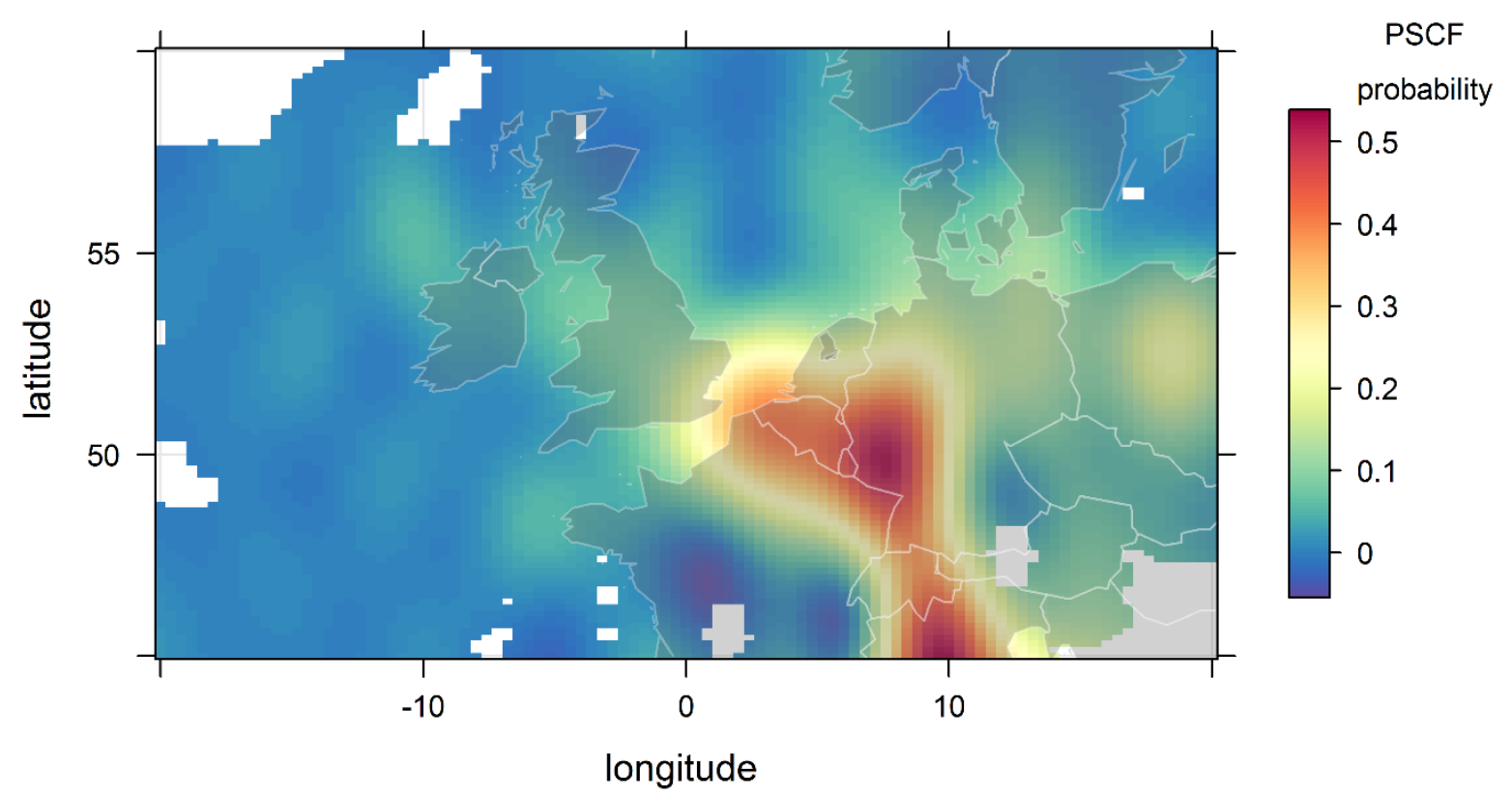

Figure 7: Potential Source Contribution Function (PSCF) plot showing that higher concentrations of TGM observed at Harwell are more likely to arrive on air masses from over Germany and continental Europe. Plot generated using OpenAir ${ }^{53}$

The concentration weighted trajectory (CWT) plot shown in Figure S4 creates a concentration field from a grid domain to identify the sources of pollutants. This method uses the concentration measured when a trajectory arrives at the site, and its residence time in each grid cell it passes through, to create a mean concentration for each grid cell ${ }^{75,}{ }^{76}$. Figure S5 shows that the Atlantic 
contribution to Harwell is in the order of $1.3-1.5 \mathrm{ng} \mathrm{m}^{-3}$, but that the highest concentrations are on air masses associated with mainland Europe. This is shown best in Figure 7, a Potential Source contribution Function (PSCF) plot. This gives the probability that a source is located at a certain latitude and longitude and takes into account the number of trajectories which passed through a grid cell and the number of times that concentration was high (greater than the $90^{\text {th }}$ percentile) when it had passed through the grid cell ${ }^{77,78}$. Figure 7 shows that there is a $50 \%$ probability that elevated levels seen at Harwell originate from air masses which have originated or passed over Italy, south-west Germany or the Benelux countries.

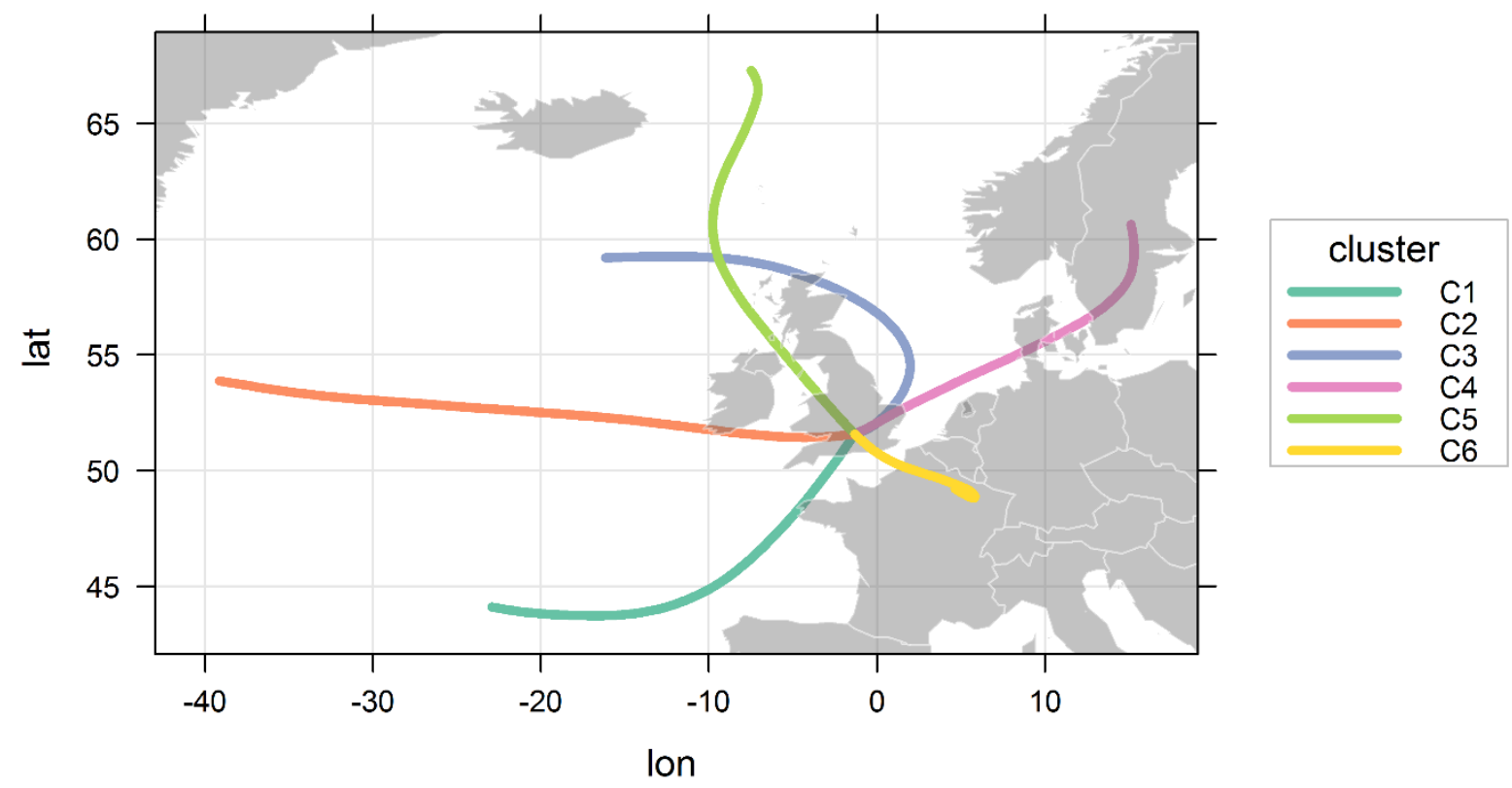

Figure 8: Cluster analysis of back trajectories arriving at Harwell with air masses of similar origins grouped into 6 average trajectory clusters. Plot generated using OpenAir ${ }^{53}$. The clusters are defined as C1: SW oceanic, C2: W oceanic, C3:N oceanic/UK, C4:NE Scandinavia, C5: NW oceanic/UK, C6: SE mainland Europe. (Generated using OpenAir.)

Cluster analysis on the back trajectories allow us to analyse the data further and draw conclusions about what affects the levels of TGM observed at Harwell. We have aggregated the air masses arriving during 2013 into 6 clusters using OpenAir, which uses an angle-based distance matrix to group trajectories with similar air mass origins (Figure 8). This then allows us to visually compare the temporal characteristics of each cluster (Figure 9). 


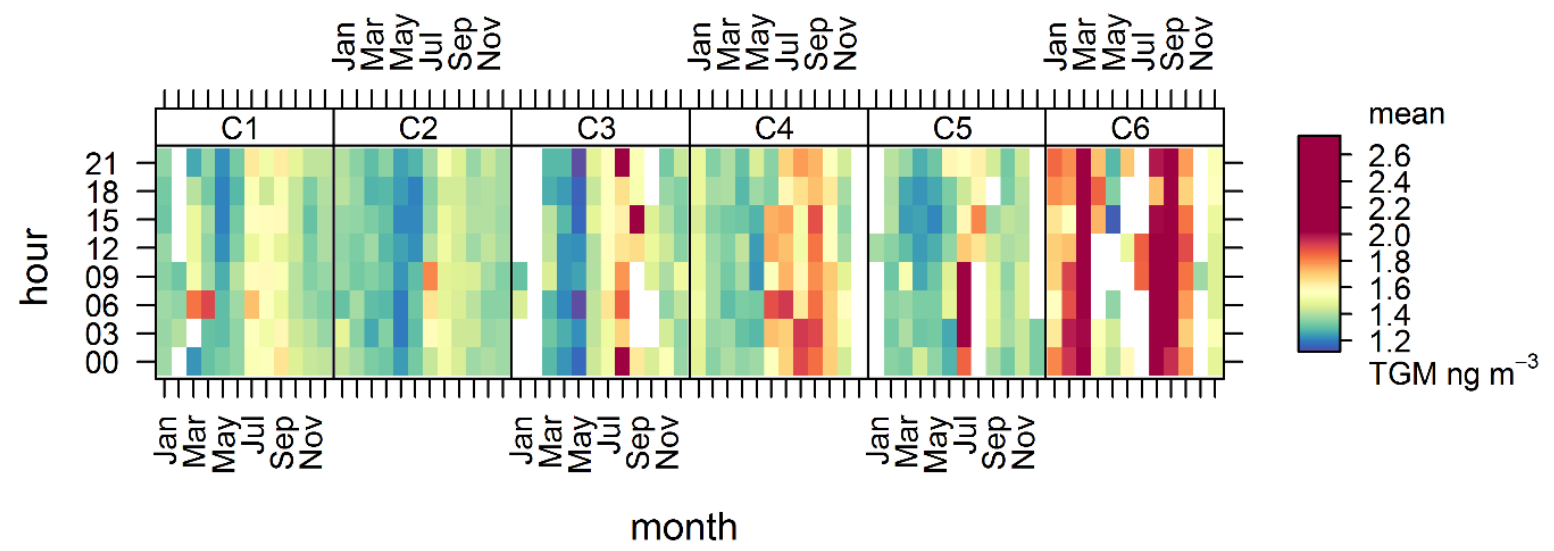

\begin{tabular}{|c|c|c|c|c|c|c|}
\hline Cluster & 1 & 2 & 3 & 4 & 5 & 6 \\
\hline Trajectories in Cluster & 607 & 1077 & 265 & 504 & 260 & 205 \\
\hline
\end{tabular}

Figure 9: The temporal characteristics of TGM levels observed at Harwell for each of the clusters, showing that cluster 6 is dominated by higher concentrations from continental Europe. The clusters are defined as C1: SW oceanic, C2: W oceanic,

C3:N oceanic/UK, C4:NE Scandinavia, C5: NW oceanic/UK, C6: SE mainland Europe. (Generated using OpenAir.)

From Figure 9 we can conclude that the highest observations of TGM originate from air masses from the continent, being relatively consistent throughout the year. Air masses in clusters 1 and 2 give few elevated TGM levels, which would be consistent with cleaner air masses from the Atlantic Ocean. Clusters 3 and 5 give higher average concentrations during the summer months, possibly bringing UK emissions from northern England to the site, whilst cluster 4 potentially brings emissions from the Baltic region. It is also evident that certain clusters have a strong seasonal pattern (clusters 3 and 4 for example), with higher levels in July, August and September, which contributes to the overall seasonal variability for the site seen earlier in Figure 2.

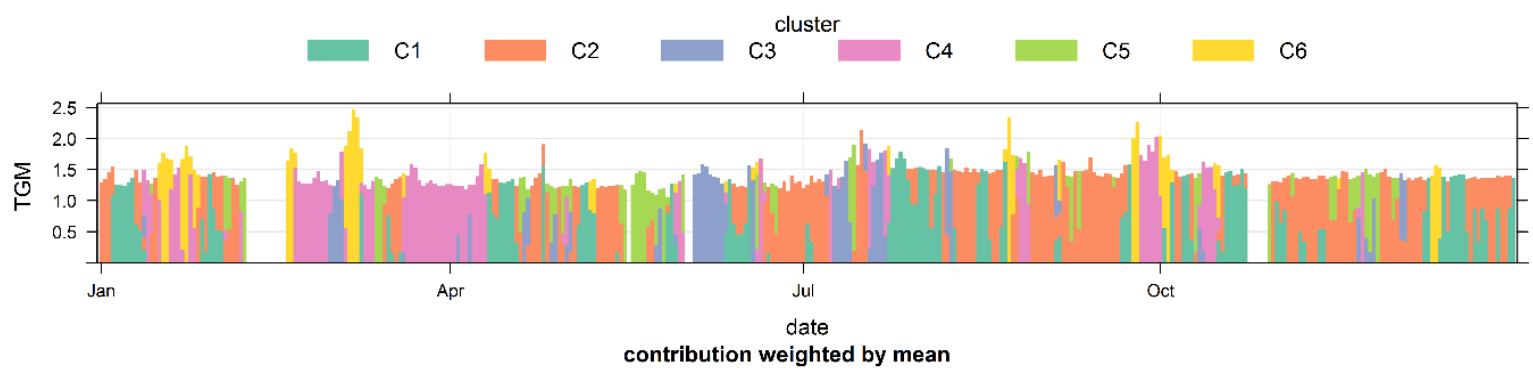

Figure 10: Temporal variation in daily average TGM $\left(\mathrm{nm} \mathrm{m}^{-3}\right)$ for the Harwell site shown by contribution by cluster. (Generated using OpenAir.)

The proportion of each air mass contributing to a daily average is shown in Figure 10. The peak levels observed are more often than not contributed by 
trajectories from C6 (yellow, continental Europe). The summer rise in TGM levels, which start with a peak in mid-July, covers a range of air mass clusters, which would indicate that the summer elevation is a feature of increasing temperatures rather than seasonal changes in a given source region. The summer maximum could therefore be a local effect at the Harwell site, related to activity in and around the Science Campus.

\section{Conclusions}

The data presented here show that levels of TGM observed at the Harwell EMEP supersite are consistent with its sister UK supersite, Auchencorth Moss, but are on average $0.05 \mathrm{ng} \mathrm{m}^{-3}$ higher. The data also indicate a $14 \%$ decline in average TGM concentration between 1995/6 and 2013, from $1.68 \mathrm{ng} \mathrm{m}^{-3}$ to $1.45 \mathrm{ng} \mathrm{m}^{-3}$. This places this study broadly in line with observations at other monitoring stations in the northern hemisphere, some of which showed a decline of between 20 and $38 \%{ }^{36,58}$.

The impact of local point sources on the levels of TGM observed are significant, with the largest contribution from the adjacent Science \& Innovation Campus, but also the Didcot $A$ coal-fired power station some $6 \mathrm{~km}$ distant. With the closure of Didcot $A$, the science campus remains the largest influence on the monitoring site, meaning Harwell is more of a 'suburban background' monitoring station, certainly when compared to Auchencorth Moss. This influence of the science campus can be seen in the temporal trends in the data, which has shown a diurnal pattern with a daytime minimum due to extensive mixing and a night time maximum due to local emissions into a nocturnal boundary layer.

However, the long-range transport of mercury also has an impact on the observed TGM concentrations, with air masses from continental Europe bringing more contaminated air from France, Germany and Italy (where there is extensive heavy industry and a greater prevalence of point sources) over the UK. Lowest levels of TGM are correlated with cleaner air masses moving in from the North Atlantic Ocean. This pattern is consistent with the observed south-east to north-west declining gradient observed across the UK ${ }^{56}$, based on a sampling network of 10 rural sites measuring TGM.

\section{Acknowledgements}


We would like to thank the UK Department for the Environment, Food and Rural Affairs who funded this work (CPEA32) on behalf of the UK Government and the Devolved Administrations (the Scottish Government, National Assembly for Wales and the Department for the Environment in Northern Ireland. We would also like to thank Ricardo-AEA, who operate the Harwell EMEP supersite.

\section{References}

1. C. H. Lamborg, C. R. Hammerschmidt, K. L. Bowman, G. J. Swarr, K. M. Munson, D. C. Ohnemus, P. J. Lam, L.-E. Heimbuerger, M. J. A. Rijkenberg and M. A. Saito, Nature, 2014, 512, 65-+.

2. D. A. Nimick, R. R. Caldwell, D. R. Skaar and T. M. Selch, Sci Total Environ, 2013, 443, 40-54.

3. M. S. Gustin, Applied Geochemistry, 2008, 23, 482-493.

4. UNEP, Global Mercury Assessment 2013: Sources, Emissions, Releases and Environmental Transport, UNEP Chemicals Branch, Geneva, Switzerland, 2013.

5. M. L. I. Witt, T. A. Mather, D. M. Pyle, A. Aiuppa, E. Bagnato and V. I. Tsanev, Journal of Geophysical Research, 2008, 113.

6. J. Carrie, G. A. Stern, H. Sanei, R. W. Macdonald and F. Wang, Applied Geochemistry, 2012, 27, 815-824.

7. N. Pirrone, S. Cinnirella, X. Feng, R. B. Finkelman, H. R. Friedli, J. Leaner, R. Mason, A. B. Mukherjee, G. B. Stracher, D. G. Streets and K. Telmer, Atmospheric Chemistry and Physics, 2010, 10, 5951-5964.

8. D. G. Streets, M. K. Devane, Z. Lu, T. C. Bond, E. M. Sunderland and D. J. Jacob, Environmental Science \& Technology, 2011, 45, 10485-10491.

9. E. G. Pacyna, J. M. Pacyna, K. Sundseth, J. Munthe, K. Kindbom, S. Wilson, F. Steenhuisen and P. Maxson, Atmospheric Environment, 2010, 44, 2487-2499.

10. Y. Wang, J. Huang, P. K. Hopke, O. V. Rattigan, D. C. Chalupa, M. J. Utell and T. M. Holsen, Chemosphere, 2013, 92, 360-367.

11. R. J. DiCosty, M. A. Callaham and J. A. Stanturf, Water Air and Soil Pollution, 2006, 176, 77-91.

12. W. H. Schroeder and J. Munthe, Atmospheric Environment, 1998, 32, 809-822.

13. S. E. Lindberg and W. J. Stratton, Environmental Science \& Technology, 1998, 32, 49-57.

14. X. Zhang, Z. Siddiqi, X. Song, K. L. Mandiwana, M. Yousaf and J. Lu, Atmospheric Environment, 2012, 50, 60-65.

15. D. S. Lee, E. Nemitz, D. Fowler and R. D. Kingdon, Atmospheric Environment, 2001, 35, 54555466.

16. X. B. Feng, J. Y. Lu, D. C. Gregoire, Y. J. Hao, C. M. Banic and W. H. Schroeder, Analytical and Bioanalytical Chemistry, 2004, 380, 683-689.

17. C. D. Holmes, D. J. Jacob, E. S. Corbitt, J. Mao, X. Yang, R. Talbot and F. Slemr, Atmospheric Chemistry and Physics, 2010, 10, 12037-12057.

18. M. Sakata and K. Marumoto, Atmospheric Environment, 2005, 39, 3139-3146.

19. S.-o. Lai, T. M. Holsen, P. K. Hopke and P. Liu, Atmospheric Environment, 2007, 41, 4337-4348.

20. M. M. Lynam, J. T. Dvonch, N. L. Hall, M. Morishita and J. A. Barres, Environmental Science and Pollution Research, 2014, 21, 4032-4043.

21. L. M. Zhang, L. P. Wright and P. Blanchard, Atmospheric Environment, 2009, 43, 5853-5864.

22. AMAP/UNEP, Technical background Report for the Global Mercury Assessment 2013, Arctic Monitoring and Assessment Programme, Oslo, Norway / UNEP Chemicals Branch, Geneva, Switzerland, 2013. 
23. C. Temme, P. Blanchard, A. Steffen, C. Banic, S. Beauchamp, L. Poissant, R. Tordon and B. Wiens, Atmos Environ, 2007, 41, 5423-5441.

24. A. Steffen, W. Schroeder, R. Macdonald, L. Poissant and A. Konoplev, Science of the Total Environment, 2005, 342, 185-198.

25. P. A. Ariya, A. P. Dastoor, M. Amyot, W. H. Schroeder, L. Barrie, K. Anlauf, F. Raofie, A. Ryzhkov, D. Davignon, J. Lalonde and A. Steffen, Tellus, 2004, 56B, 397 - 403.

26. E. Tas, D. Obrist, M. Peleg, V. Matveev, X. Fain, D. Asaf and M. Luria, Atmospheric Chemistry and Physics, 2012, 12, 2429-2440.

27. E. G. Brunke, C. Labuschagne, R. Ebinghaus, H. H. Kock and F. Slemr, Atmospheric Chemistry and Physics, 2010, 10, 1121-1131.

28. D. M. Feddersen, R. Talbot, H. Mao and B. C. Sive, Atmospheric Chemistry and Physics, 2012, 12, 10899-10909.

29. D. S. Lee, G. J. Dollard and S. Pepler, Atmospheric Environment, 1998, 32, 855-864.

30. A. P. Rowland, A. J. Lawlor, H. J. Guyatt and R. A. Wadsworth, Journal of Environmental Monitoring, 2010, 12, 1747-1755.

31. L. D. Lacerda, Water Air and Soil Pollution, 1997, 97, 209-221.

32. D. R. Engstrom, W. F. Fitzgerald, C. A. Cooke, C. H. Lamborg, P. E. Drevnick, E. B. Swain, S. J. Balogh and P. H. Balcom, Environmental Science \& Technology, 2014, 48, 6533-6543.

33. P. Schuster, D. P. Krabbenhoft, D. L. Naftz, L. D. Cecil, M. L. Olson, J. F. Dewild, D. D. Susong, J. R. Green and M. L. Abbot, Environ. Sci. Technol., 2002, 36, 2303 - 2310.

34. J. G. Farmer, P. Anderson, J. M. Cloy, M. C. Graham, A. B. MacKenzie and G. T. Cook, Science of the Total Environment, 2009, 407, 5578-5588.

35. H. D. Yang, N. L. Rose, R. W. Battarbee and J. F. Boyle, Environmental Science \& Technology, 2002, 36, 1383-1388.

36. F. Slemr, E. G. Brunke, R. Ebinghaus and J. Kuss, Atmospheric Chemistry and Physics, 2011, 11, 4779-4787.

37. A. L. Soerensen, D. J. Jacob, D. G. Streets, M. L. I. Witt, R. Ebinghaus, R. P. Mason, M. Andersson and E. M. Sunderland, Geophys Res Lett, 2012, 39.

38. F. Sprovieri, N. Pirrone, R. Ebinghaus, H. Kock and A. Dommergue, Atmospheric Chemistry and Physics, 2010, 10, 8245-8265.

39. M. L. Abbott, C.-L. Lin, P. Martian and J. Einerson, Applied Geochemistry, 2008, 23, 438 - 453.

40. L. Poissant, M. Pilote, C. Beauvais, P. Constant and H. H. Zhang, Atmospheric Environment, 2005, 39, 1275-1287.

41. M. Harada, Critical Reviews in Toxicology, 1995, 25, 1-24.

42. P. Holmes, K. A. F. James and L. S. Levy, Science of the Total Environment, 2009, 408, 171-182.

43. C. T. Driscoll, R. P. Mason, H. M. Chan, D. J. Jacob and N. Pirrone, Environmental Science \& Technology, 2013, 47, 4967-4983.

44. S. W. Tan, J. C. Meiller and K. R. Mahaffey, Critical Reviews in Toxicology, 2009, 39, 228-269.

45. J. A. Davis, R. E. Looker, D. Yee, M. Marvin-Di Pasquale, J. L. Grenier, C. M. Austin, L. J. McKee, B. K. Greenfield, R. Brodberg and J. D. Blum, Environ. Res., 2012, 119, 3-26.

46. Y.-S. Hong, Y.-M. Kim and K.-E. Lee, Journal of preventive medicine and public health = Yebang Uihakhoe chi, 2012, 45, 353-363.

47. A. M. Lando, S. B. Fein and C. J. Choiniere, Environ. Res., 2012, 116, 85-92.

48. UNEP, ed. U. N. E. Programme, Geneva, Switzerland, Editon edn., 2013.

49. Defra, Site Information for Harwell (UKA00047), http://uk-air.defra.gov.uk/networks/siteinfo?site id=HAR, Accessed 5/8/2014, 2014.

50. K. Torseth, W. Aas, K. Breivik, A. M. Fjaeraa, M. Fiebig, A. G. Hjellbrekke, C. L. Myhre, S. Solberg and K. E. Yttri, Atmospheric Chemistry and Physics, 2012, 12, 5447-5481.

51. Tekran, Model 2537A Mercury Vapor Analyzer User Manual, 2.21 edn., Toronto, Canada, 1999. 
52. Tekran, The Tekran Ambient Monitoring System: Continuous Ultra-Trace mercury Vapor Analysis, 2009.

53. R. R. Draxler and G. D. Rolph, HYSPLIT (HYbrid Single-Particle Lagrangian Inetgrated Trajectory) Model, http://ready.arl.noaa.gov/HYSPLIT.php, 2014.

54. D. C. Carslaw and K. Ropkins, Environmental Modelling \& Software, 2012, 27-28, 52-61.

55. R. C. Team, Foundation for Statistical Computing, Vienna, Austria, Editon edn., 2012.

56. J. Kentisbeer, S. R. Leeson, H. M. Malcolm, I. D. Leith, C. F. Braban and J. N. Cape, Environmental Science-Processes \& Impacts, 2014, 16, 1112-1123.

57. J. Kentisbeer, D. Leaver and J. N. Cape, Journal of Environmental Monitoring, 2011, 13, $1653-$ 1661.

58. R. Ebinghaus, S. G. Jennings, H. H. Kock, R. G. Derwent, A. J. Manning and T. G. Spain, Atmospheric Environment, 2011, 45, 3475-3480.

59. U. S. Nair, Y. L. Wu, J. Walters, J. Jansen and E. S. Edgerton, Atmospheric Environment, 2012, 47, 499-508.

60. H. D. Choi, J. Huang, S. Mondal and T. M. Holsen, Sci Total Environ, 2013, 448, 96-106.

61. B. Liu, G. J. Keeler, J. T. Dvonch, J. A. Barres, M. M. Lynam, F. J. Marsik and J. T. Morgan, Atmospheric Environment, 44, 2013-2023.

62. I. Wängberg, J. Munthe, T. Berg, R. Ebinghaus, H. H. Kock, C. Temme, E. Bieber, T. G. Spain and A. Stolk, Atmospheric Environment, 2007, 41, 2612-2619.

63. R. Ebinghaus, H. H. Kock, A. M. Coggins, T. G. Spain, S. G. Jennings and C. Temme, Atmospheric Environment, 2002, 36, 5267-5276.

64. H. H. Kock, E. Bieber, R. Ebinghaus, T. G. Spain and B. Thees, Atmospheric Environment, 2005, 39, 7549 - 7556.

65. A. Weigelt, C. Temme, E. Bieber, A. Schwerin, M. Schuetze, R. Ebinghaus and H. H. Kock, Environ. Chem., 2013, 10, 102-110.

66. D. A. Gay, D. Schmeltz, E. Prestbo, M. Olson, T. Sharac and R. Tordon, Atmospheric Chemistry and Physics, 2013, 13, 11339-11349.

67. J. Stamenkovic, S. Lyman and M. S. Gustin, Atmospheric Environment, 2007, 41, 6662-6672.

68. J. M. Sigler, H. Mao, B. C. Sive and R. Talbot, Atmospheric Chemistry and Physics, 2009, 9, 40234030.

69. L. E. Gratz, G. J. Keeler, F. J. Marsik, J. A. Barres and J. T. Dvonch, Sci Total Environ, 2013, 448, 84-95.

70. K.-H. Kim, R. Ebinghaus, W. H. Schroeder, P. Blanchard, H. H. Kock, A. Steffen, F. A. Froude, M.-Y. Kim, S. Hong and J.-H. Kim, J. Atmos. Chem., 2005, 50, 1-24.

71. S. E. Rothenberg, L. McKee, A. Gilbreath, D. Yee, M. Connor and X. W. Fu, Atmospheric Environment, 44, 1263-1273.

72. X. Lan, R. Talbot, M. Castro, K. Perry and W. Luke, Atmospheric Chemistry and Physics, 2012, 12, 10569-10582.

73. Defra, UK Pollutant Release \& Transfer Register, http://prtr.defra.gov.uk/pollutant-releases, Accessed 03/09/2014, 2014.

74. S. Grant, Personal Communication.

75. P. Seibert, H. Kromp-Kolb, U. Baltensperger, D. T. Jost and M. Schwikowski, in NATO Challenges of Modern Society; Air pollution modeling and its application X, eds. S. E. Gryning and M. M. Millan, Plenum Press, 233 Spring Street, New York, New York, USA; Plenum Press, London, England, UK, Editon edn., 1994, vol. 18, pp. 595-596.

76. A. Lupu and W. Maenhaut, Atmospheric Environment, 2002, 36, 5607-5618.

77. Z. L. Fleming, P. S. Monks and A. J. Manning, Atmospheric Research, 2012, 104, 1-39.

78. N. J. Pekney, C. I. Davidson, L. Zhou and P. K. Hopke, Aerosol Science and Technology, 2006, 40, 952-961. 
